\title{
PENGARUH KOMUNIKASI INTERPERSONAL SEBAGAI HUMAN CAPITAL TERHADAP PENINGKATAN KEUNGGULAN KOMPETITIF SDM PADA INDUSTRI PARIWISATA BANGKA
}

\author{
Ida R. Damayanti \\ STISIPOL PAHLAWAN 12, Jl. Diponegoro No. 16, Sungailiat, Bangka 33215
}

Telp/Fax. (0717) 92750

Yera Yulista

IAIN Syaikh Abdurrahman Siddik Babel, Jl. Raya Petaling Km.13, Mendobarat, Bangka 33173

\begin{abstract}
ABSTRAK
Ketertarikan wisatawan untuk mengunjungi obyek wisata tidak hanya sekedar diukur dari indahnya obyek wisata, fasilitas yang diberikan namun pelayanan yang diberikan jauh lebih berarti dan patut diperhatikan oleh pelaku bisnis pariwisata. Komunikasi interpersonal yang baik dan mudah dimengerti merupakan bagian dari modal manusia sebagai bentuk keunggulan kompetitif Sumber Daya Manusia, apalagi saat ini Indonesia sudah memasuki MEA jelas persaingan semakin melebar, artinya jika persaingan berskala internasional ini tidak disikapi secara maksimal tentunya akan menimbulkan lesunya dunia bisnis khususnya sektor pariwisata di Pulau Bangka yang merupakan bagian dari Propinsi Kep. Babel. Penelitian ini dilakukanuntuk mengetahui pengaruh komunikasi interpersonal sebagai human kapital terhadap keunggulan kompetitif sumber daya manusia pada industri pariwisata Bangka. Penelitian ini menggunakan metode survey dengan menyebarkan kuesioner kepada 100 responden populasi yang dalam penelitian ini adalah masyarakat Bangka yang terdiri dari 5 kabupaten kota di Pulau Bangka. Pengujian statistik menggunakan analisis regresi linier sederhana, dengan tingkat kepercayaan 95\%. Hasil dan pembahasan ini menunjukkan bahwa komunikasi interpersonal sebagai modal manusia berpengaruh positif dan signifikan pada keunggulan kompetitif sumber daya manusia di industri Pariwisata Bangka.
\end{abstract}

Kata Kunci: komunikasi interpersonal, keunggulan kompetitif 


\section{PENDAHULUAN}

Ekonomi dunia telah mengalami perubahan besar sejak pertumbuhan perdagangan internasional dan perilaku konsumen yang heterogen yang suka tidak suka kita harus menerima perubahan tersebut dan ikut berpartisipasi dalam kancah persaingan di dalamnya. Pertanyaan yang paling mendasar adalah, apakah tenaga kerja Indonesia bisa bersaing dengan negara negara Asia lainnya yang semakin ketat pada era MEA (Masyarakat Ekonomi ASEAN), dimana tenaga kerja asing telah memiliki akses untuk bisa bekerja di wilayah kesatuan negara Republik Indonesia yang berimplikasi akan semakin berkurang bagi tenaga kerja Indonesia untuk menempati posisi kerja pada dunia usaha yang ada di Indonesia yang semakin kompleks.

MEA juga merupakan pintu gerbang atau akses bagi wirausahawan untuk memberikan peluang bagi para pencari kerja terbaik sesuai dengan kriteria yang diinginkan dan ini tentunya akan menimbulkan tingkat persaingan yang sangat ketat pada sumber daya manusia yang kita miliki maka dibutuhkan pengelolaan sumber daya manusia secara baik melalui pemberdayaan SDM. Jika dilihat dari sisi pendidikan, Indonesia tidak kalah dalam bersaing dengan tenaga kerja Asia lainnya, akan tetapi kompetensi, skill dan kinerja SDM kita masih tertinggal jauh jika dibandingkan dengan SDM dari negara ASEAN lainnya. Persaingan yang ketat tersebut jangan dijadikan sebagai ketakutan yang tidak berdasar, mari kita jadikan sebagai momen awal bagi para pelaku usaha untuk lebih meningkatkan kompetensi dan kualitas diri SDM agar mampu bersaing dengan para pencari kerja lainnya.

Penelitian ini bertitik tolak dari kondisi semakin ketatnya persaingan dunia kerja dan dunia usaha dalam rangka menghadapi pasar global, pulau Bangka adalah pulau yang merupakan bagian dari Propinsi Kepulauan Bangka Belitung (Babel). Industri pariwisata daerah Babel khususnya wilayah Bangka memiliki potensi dan daya tarik tersendiri dan ini merupakan sebuah peluang yang sangat besar dalam persaingan global.

Pariwisata adalah salah satu sektor yang cukup menarik untuk dikaji dalam hubunganya dengan sumber daya manusia karena banyak pihak yang terlibat baik para pelaku pariwisata itu sendiri ataupun para pengguna jasa pariwisata itu sendiri yang lebih dikenal dengan wisatawan. Menariknya sektor ini dapat memberikan pelayanan bagi segala usia. Satu hal yang harusnya disadari untuk menarik para wisatawan di pulau ini keindahan alam saja tidaklah cukup. Harus ada hal lain yang tidak kalah penting untuk dimaksimalkan sehingga dapat menarik minat wisatawan untuk datang kesini yakni dalam memberikan pelayanan. Pelayanan tidak lepas dari bagaimana cara seseorang yang dalam hal ini para pelaku pariwisata melakukan interaksi dengan para wisatawan.

SDM merupakan tantangan yang cukup berat bagi pengembangan pariwisata, karena SDM sangat menentukan keberlangsungan sektor pariwisata. Harus kita akui SDM sektor pariwisata masih rendah di bawah negara ASEAN lainnya, maka perlu diadakan pembenahan sesuai standar mutu yang sesuai dengan tuntutan pasar internasional. Diakui atau tidak SDM sektor pariwisata masih banyak memiliki kelemahan dan jauh dari profesionalisme. Rendahnya sumber daya manusia, terutama tenaga yang terampil dan profesional dalam hal manajerial di bidang pariwisata merupakan kendala yang seringkali ditemukan. 
Pengaruh modal manusia dan perannya manajemen sumber daya manusia akan ikut membantu dalam membangun keunggulan kompetitif atau daya saing sektor SDM. Menyadari hal tersebut, peningkatan kualitas SDM menjadi sebuah keharusan diyakini memiliki kontribusi sangat besar adalah komunikasi interpersonal dari sumber daya manusianya sebagai modal manusia dalam rangka memasarkan produk pariwisata tersebut.

Dalam buku Human Capital Competency A.M. Lilik Agung mengatakan bahwa salah satu dari empat peran sumber daya manusia adalah menempatkan manusia sebagai modal perusahaan yang menjadi agen perubahan dan transformasi organisasi (management of transformation agent and change) dan mitra dalam menentukan strategi perusahaan (management of strategic human resources). Peran human capital saat ini sangat strategis dan penting sekali dalam dunia bisnis yang serba dinamis. Human capital merupakan pengetahuan, ketrampilan dan kemampuan seseorang yang dapat digunakan untuk menghasilkan layanan yang profesional dan oleh karena itu ketrampilan dan kemampuan serta pengetahuan yang dimiliki dapat kita jadikan sebagai modal/capital dari manusianya sebagai pelaku bisnis di bidang jasa pariwisata.

Definisi pariwisata menurut Undangundang Nomor 10 Tahun 2009 pasal 1, "Wisata adalah kegiatan perjalanan yang dilakukan oleh seseorang atau sekelompok orang dengan mengunjungi tempat tertentu untuk tujuan rekreasi, pengembangan pribadi, atau mempelajari keunikan daya tarik wisata yang dikunjungi dalam jangka waktu sementara”.

"Pariwisata adalah berbagai macam kegiatan wisata dan didukung berbagai fasilitas serta layanan yang disediakan oleh masyarakat, pengusaha, pemerintah, dan Pemerintah Daerah".

Di samping memiliki pantai yang indah, Bangka sendiri memiliki aneka ragam budaya seperti Melayu, Cina dan Bangka. Pulau Bangka juga kaya akan keindahan pantainya yang identik dengan sektor pariwisata dan kelautan. Keindahan alam yang dimiliki menjadi alasan wisatawan melakukan destinasi ke pulau ini. Saat ini memang sektor pariwisata di pulau ini sedang giat-giatnya dilakukan. Untuk mencapai tujuan pariwisata yang berkelanjutan, baik secara ekonomi, sosial-budaya, dan lingkungan. Pengelola hendaknya melakukan manajemen sumber daya yang efektif baik itu pemanfaatan pengelolaan sumber daya menjadi objek wisata, maupun pembenahan SDM dan ekspansi jenis pariwisata lain yang bisa didapatkan wisatawan ketika mereka datang ke pulau ini.

Saat ini ada beberapa jenis pariwisata yang ada di pulau ini. Hampir setiap tahunya mengadakan event budaya untuk menarik para wisatawan baik wisatawan domestik maupun mancanegara, misalnya acara 10 Muharam bisa dijadikan sebagai ajang promosi pariwisata budaya lokal yang diadakan pada bulan Oktober setiap tahunya, belum lagi acara tradisi keagaamaan nganggung yang diadakan guna mempererat tali silaturahmi dan budaya gotong-royong yang hanya terdapat di daerah Babel dan masih banyak lagi even yang dapat menarik wisatawan.

Pariwisata merupakan industri perdagangan dan jasa yang melibatkan berbagai hal seperti transportasi, tempat penginapan, pemandu wisata, restoran dan biro perjalanan. Industri pariwisata adalah suatu bentuk kegiatan yang terdiri dari berbagai macam bidang usaha yang tidak lepas dari manusia dalam pengelolaannya, maka dibutuhkan sumber daya manusia yang handal 
dan terampil. Sumber daya manusia atau human resources adalah aset utama bagi pemerintah daerah karena sumber daya manusia memegang peranan penting dalam segala hal menyangkut kegiatan usaha.

Sebenarnya bisa dikatakan suatu berkah apabila sektor ini dapat disikapi keberadaannya. Sebut saja salah satunya potensi alam yang diberikan Tuhan Yang Maha Esa dikelola semenarik mungkin dengan cara dilestarikan keberadaannya dapat membuat orang tertarik menikmatinya, tidak hanya dari masyarakat setempat saja bahkan dari penjuru dunia lain bisa saja memanfaatkan peluang itu tidak sekadar dikunjungi atau dijadikan tujuan lain misalkan menjadi lokasi shooting sebuah film. Apalagi kita tahu Indonesia kaya sekali dengan sumber daya alam yang eksotik. Tentang hal ini kemajuan teknologi tidak lepas ikut membantu mempromosikan keberadan pariwisata ini baik melalui situs pariwisata, media social, atau bahkan bentuk promosi yang memiliki magnet kuat yakni komunikasi mulut ke mulut atau word of mouth (WOM).

Jika objek pariwisata itu memiliki nilai (value) akan lebih mudah digaungkan sehingga akan mudah pula diketahui oleh banyak pihak apalagi saat ini hobi traveling semakin menjadi meningkat bagi kebanyakan kalangan yang seperti disebutkan di atas dapat menjadi "obat" bagi pengguna pariwisata. Kemudahan menikmati objek pariwisata ini tentunya tidak lepas dari keseriusan para penggiat pelaku pariwisata itu sendiri merasakan ada profit tersendiri apabila dapat memaksimalkan pelayanan sektor ini sehingga dapat mendukung kemajuan ekonomi masyarakat setempat.

Kita tahu beberapa para pelaku pariwisata ini apabila sektor ini dikelola dengan serius akan menaikkan kesejahteraan masyarakat khususnya masyarakat lokal yang berada di wilayah sektor kepariwisataan itu sendiri. Hal ini cukup berarti karena warga bisa saja memanfaatkan peluang ini untuk bisnis entah itu mendirikan penginapan, kuliner, kerajinan, biro perjalanan, pemandu wisata, dan bagi pemerintah khususnya sektor ini jelas dapat memberikan penambahan pendapatan bagi daerah.

Komunikasi interpersonal lebih identik dengan komunikasi tatap muka. Dengan bertatap muka secara langsung akan memberikan suatu kesan tentang seseorang. Sehingga tidaklah salah jika kita mendengar "kesan pertama begitu menggoda" memang betul adanya. Kesan pertama akan menjadi penilaian bagi citra pada pelayanan pariwisata itu sendiri apakah para wisatawan hanya sekadar saja arti penting kehadiran mereka atau sebaliknya. Komunikasi yang baik dalam memberikan pelayanan baik dari bahasa verbal berupa bahasa atau non verbal akan memiliki makna seberapa berartinya kehadiran para wisatawan. Tentunya jika komunikasi yang baik dapat diciptakan oleh para pelaku bisnis ini maka akan membuat wisatawan merasakan nyaman hadir dalam lingkungan pariwisata tersebut, pun sebaliknya jika komunikasi yang dibangun hanya sekadar saja maka akan menimbulkan kesan ketidakramahan dan kesan kurang menyenangkan lainnya.

Terlihat sederhana apabila berbicara komunikasi interpersonal ini namun memiliki pengaruh yang kuat bagi keberlangsungan sektor ini sendiri. Lalu seperti apakah komunikasi interpersonal yang selama ini sudah dibangun dalam memberikan pelayanan kepada wisatawan? Sring kita dengar dalam kehidupan masyarakat Bangka itu identik dengan bahasa "dak kawa nyusah" (tidak mau bersusah payah). Apakah 
pada akhirnya anggapan ini juga berlaku tidak mau bersusah payah dalam berkomunikasi hal ini menjadi menarik untuk diteliti. Dalam kaitannya dalam tulisan ini permasalahan yang akan diteliti adalah apakah komunikasi interpersonal sebagai modal manusia dari pelaku bisnis pariwisata akan berpengaruh terhadap peningkatan keunggulan sumber daya manusia pada industri pariwisata di era masyarakat ekonomi ASEAN.

\section{Komunikasi Interpersonal}

Komunikasi interpersonal adalah komunikasi antar seorang komunikator dengan seorang komunikan, yang juga dapat terjadi antar seorang komunikator dengan sekelompok kecil (small group) orang, mendapatkan umpan balik yang dapat langsung diterima dari audiens oleh komunikator. Komunikasi jenis ini dianggap paling efektif dalam hal upaya mengubah sikap, pendapat, atau perilaku seseorang, karena sifatnya yang dialogis, berupa percakapan. (Josep Devito, 1995: 7). Komunikasi ini sering disebut sebagai komunikasi persuasif (persuasive communication) yakni suatu teknik komunikasi seara psikologis manusiawi yang sifatnya halus, luwes berupa ajakan, bujukan atau rayuan.

Pentingnya suatu komunikasi interpersonal karena prosesnya memungkinkan berlangsung secara dialogis. Dialog adalah bentuk komunikasi antar pribadi yang menunjukkan terjadinya interaksi. Komunikasi antarpribadi (interpersonal communication) adalah komunikasi antara orang-orang secara tatap muka, yang memungkinkan setiap pesertanya menangkap reaksi orang lain secara langsung,baik verbal maupun nonverbal (Mulyana, 2004)
Devito, 1989 menyatakan: "The five major purposes of interpersonal communication are to learn about self, others, and the world; to relate to others and to form relationship; to influence or control the attitudes and behaviours of others; to play or enjoy oneself; to help others."

Menurut Devito tujuan komunikasi interpersonal diantaranya adalah:

a. Untuk belajar tentang diri sendiri, tentang orang lain, bahkan tentang dunia. Melalui kegiatan komunikasi interpersonal dengan seseorang, kita bisa mengetahui siapa dia dan juga mengetahui bagaimana pendapat dia tentang kita, sehingga kita pun menjadi tahu seperti apa kita.

b. Untuk berhubungan dengan orang lain dan untukmembangun suatuikatan (relationship). Melalui komunikasi interpersonal kita dapat berkenalan dengan seseorang dan komunikasi interpersonal yang intensif dan efektif bisa menciptakan suatu ikatan batin yang erat. Hal ini terjadi ketika kita membangun dan memelihara persahabatan dengan orang lain yang sebelumnya tidak kita kenal.

c. Untuk mempengaruhi sikap dan perilaku orang lain. Dalam hal ini kegiatan komunikasi ditujukan untuk memengaruhi atau membujuk agar orang lain memiliki sikap, pendapat dan atau perilaku yang sesuai dengan tujuan kita.

\section{Faktor-Faktor yang Mempengaruhi \\ Komunikasi Interpersonal}

a. Persepsi Interpersonal

Persepsi seseorang terhadap orang lain, tidak senantiasa cermat dan benar. Seringkali terjadi bahwa apa yang diterima dan dipahami 
oleh komunikan tidak sesuai dengan apa yang disampaikan dan diinginkan oleh komunikator. Dalam hal ini akan terjadi kegagalan dalam berkomunikasi apabila antara komunikator dan komunikan tidak dapat menanggapi dengan cermat

b. Konsep Diri

Konsep diri merupakan keadaan di mana seorang individu berusaha untuk mengamati, mencari gambaran, dan memberikan penilaian terhadap dirinya sendiri. William D. Brooks. Orang yang mengalami kesulitan untuk mengkomunikasikan gagasannya kepada orang lain, cenderung tidak mampudan menghindari pembicaraan dengan orang lain.

c. Atraksi Interpersonal

Atraksi interpersonal dalam komunikasi interpersonal dapat berpengaruh pada penafsiran dan penilaiaan terhadap pesan yang dikirim oleh komunikator. Selain itu, atraksi interpersonal juga berdampak pada efektifitas komunikasi karena suasanadan pertemuan dalam komunikasi dianggap sebagai hal yang menyenangkan oleh komunikan.

\section{Keunggulan Kompetitif}

Konsep ini dikembangkan oleh Michael E. Porter (1990) dalam bukunya berjudul "The Competitive Advantage of Nations" yang menyatakan bahwa keunggulan bersaing menurut Porter adalah kemampuan suatu perusahaan untuk meraih keuntungan ekonomis di atas laba yang mampu diraih oleh pesaing di pasar dalam industri yang sama. Perusahaan yang memiliki keunggulan kompetitif senantiasa memiliki kemampuan dalam memahami perubahan struktur pasar dan mampu memilih strategi pemasaran yang efektif.

Sedangkan menurut Forysth, daya saing adalah power dalam artian ability atau kemampuan yang merupakan natural skill dalam melakukan sesuatu, sedangkan saing atau compete adalah kompetisi atau usaha untuk lebih unggul. Jadi keunggulan daya saing atau kompetitif adalah kemampuan kerja seseorang untuk melebihi orng lain, sehingga keberhasilan seseorang tergantung dari kegagalan individu yang lain. Menurut Cravens (1996) bahwa, "keunggulan bersaing atau keunggulan kompetitif merupakan perkembangan dari nilai yang mampu diciptakan perusahaan untuk pembelinya" Keunggulan kompetitif adalah keunggulan melebihi pesaing yang diperoleh dengan menawarkan nilai yang lebih besar kepada konsumen daripada tawaran pesaing (Kotler, 2008).

Dalam bukunya Porter menyatakan bahwa SDM mempengaruhi keunggulan bersaing melalui motivasi kerja, pelatihan dan keterampilan yang dimiliki. Jika orang atau manusianya yang menjadi sumber keunggulan dalam bersaing, mereka harus memiliki beberapa informasi yang berkaitan untuk mencapai sukses, karena informasi merupakan kunci dari sebuah persaingan. Sumber daya manusia atau human resources adalah aset utama bagi perusahaan, karena sumber daya manusia memegang peranan penting dalam segala hal menyangkut kegiatan perusahaan.

Peran human capital saat ini sangat strategis dan penting sekali dalam dunia bisnis yang serba dinamis. Human capital merupakan pengetahuan, ketrampilan dan kemampuan seseorang yang dapat di gunakan untuk menghasilkan layanan yang profesional. Oleh karena itu dibutuhkan sumber daya manusia yang berpengetahuan, berkualitas, dan berdaya saing sehingga mampu untuk menuju lingkungan yang kompetitif. 
Konsep utama dari human capital menurut Becker, (1993) adalah bahwa manusia bukan sekedar sumber daya namun merupakan modal (capital) yang menghasilkan pengembalian (return) dan setiap pengeluaran yang dilakukan dalam rangka mengembangkan kualitas dan kuantitas modal. Sedangkan Davenport (1999) mengulas penerapan human capital dari sudut pandang karyawan, sehingga tercipta istilah karyawan/investor dimana karyawan sebagai pemilik modal.

Untuk memperoleh suatu keunggulan bersaing, perusahaan harus menganalisa sumber-sumber daya yang dimiliki untuk mengidentifikasi kelemahan-kelemahan dan kekuatan-kekuatannya dalam rangka membangun suatu kemampuan (capability) untuk mencapai keunggulan. Menurut Dubé \& Renaghan (dalam Petzer, 2008), keunggulan bersaing juga dapat dilihat sebagai nilai yang dapat diciptakan oleh perusahaan untuk mendiferensiasikan dirinya dari para pesaingnya. Nilai yang diciptakan tersebut dapat diukur melalui harga yang rela dibayar oleh konsumen untuk layanan jasa yang diberikan. Keunggulan bersaing akan membangun kecakapan untuk performa aktivitas yang ebih dari lawan usaha atau lebih efektif dari pesaing, dengan kata lain perusahaan membangun keunggulan bersaing ketika memanfaatkan kekuatan untuk beberapa aktivitas lebih dari performanya (A Pit,1996).

\section{Jenis-Jenis Keunggulan Bersaing yaitu:}

a. Keunggulan biaya merupakan inti dari setiap strategi bersaing. Untuk mencapai keunggulan biaya, sebuah perusahaan harus bersiap menjadi produsen berbiaya rendah dalam industrinya.

\section{b. Diferensiasi.}

Pemilihan produk di antara banyaknya tawaran yang ada di pasar selalu didasarkan pada adanya perbedaan,perusahaan harus menjadi "unik" secara umum dihargai oleh pembeli, jadi perusahaan dihargai karena keunikannya.

\section{Faktor-Faktor yang Mempengaruhi Keunggulan Bersaing}

Menurut Crown ada beberapa faktor yang mempengaruhi keunggulan bersaing.Pendekatan yang dilakukan oleh Logenecker, Moore dan Petty (2003:30) dalam menciptakan keunggulan bersaing didasarkan atas dimensi harga/nilai, keunikan layanan, atribut produk dan pengalaman pelanggan serta kenyamanan pelanggan.

\section{a. Nilai / Value}

Yang harus ditekankan pada nilai atau value ini yaitu suatu perusahaan harus tau tentang apa nilai atau value yang diinginkan atau diharapkan oleh calon pembeli, sesuai atau tidak dengan harapan merka, atau sesuai atau tidak dengan apa yang didapatkan oleh mereka dari produk perusahaan tersebut.

b. Keunikan layanan

Keunikan dicirikan oleh barang dan jasa yang dihasilkan perusahaan tidak dapat mudah ditiru oleh pesaing.

c. Harga

Sesuai atau tidaknya harga yang ditetapkan oleh perusahaan terhadap produknya dimata konsumen atau pembeli produk tersebut. 


\section{d. Loyalitas Konsumen}

Tercipta sekelompok pembeli dalam pasar (segmen) yang akan mengabaikan prodak pengganti dari pesaing, dengan kata lain adanya loyalcustomer atau pelanggan yang setia.

\section{METODE}

Metode pengumpulan data dalam penulisan untuk memperoleh data yang diperlukan maka penulis mengunakan penelitian lapangan (Field Research), yaitu penelitian yang dilakukan untuk mengumpulkan data primer melalui observasi dengan cara memberikan kuesioner kepada responden,penelitian kepustakaan (Library Research), yaitu yang dilakukan dengan membaca buku-buku yang berhubungan dengan masalah yang diteliti ataupun dengan cara browsing di internet untuk mencari artikelartikel atau data-data yang dapat membantu hasil dari penelitian. Di samping itu juga penulis membagikan kuesioner kepada responden untuk mengisi item-item yang telah disediakan sebagai instrumen penelitian ini yaitu dengan menggunakan skala Likert dengan skor: 5 (sangat setuju), 4 (setuju), 3 (netral), 2 (tidak setuju), 1 (sangat tidak setuju).

Jenis penelitian ini adalah penelitian kuantitatif yaitu penelitian yang menekankan pada pengujian teori-teori melalui pengukuran variabel-variabel penelitian.

Populasi penelitian ini adalah seluruh masyarakat dari lima kabupaten kota wilayah Bangka. Sampel penelitian ditarik dengan teknik accidental sampling atau sampel kebetulan, maksudnya yaitu penulis memilih siapa saja yang secara acak/kebetulan ditemuinya dan dianggap cocok sebagai sumber data. Untuk menghindari sampel yang bias maka sampelnya adalah pengguna jasa tour \& Travel, tamu-tamu hotel yang menyebar di lima kabupaten kota dan masyarakat pengguna jasa bandara serta karyawan dan staf perusahaan di bidang jasa perhotelan dan pariwisata daerah Bangka.

Tabel I

\begin{tabular}{|l|l|l|}
\hline No. & Kabupaten Kota & Jumlah Penduduk \\
\hline 1 & Bangka & 311.085 \\
\hline 2 & Pangkal Pinang & 196.202 \\
\hline 3 & Bangka Barat & 196.598 \\
\hline 4 & Bangka Tengah & 180.903 \\
\hline 5 & Bangka Selatan & 193.583 \\
\hline & Jumlah & 1.078 .371 \\
\hline
\end{tabular}

Sumber: Proyeksi Penduduk Indonesia

$$
\text { 2010-2035 BPS }
$$

Dalam penelitian ini adalah probability random sampling menggunakan cluster sampling untuk menentukan area sampling. Area sampling dibagi menjadi 5 sesuai dengan wilayah Kabupaten/Kota. Agar responden (sampel) yang diambil dalam penelitian ini dapat mewakili populasi maka jumlah responden ditentukan menurut rumus Slovin (Rusadi Ruslan, 2005), sebagai berikut:

Rumus Slovin:

Keterangan:

n: ukuran sampel

$\mathrm{N}$ : ukuran populasi

E: tingkat kesalahan pengambilan sampel yang masih bisa ditolelir dari jumlah populasi tersebut dan tingkat kesalahan sebesar $10 \%$.

$$
\mathrm{n}=99.99 \rightarrow 100
$$

Uji validitas penelitian ini akan menggunakan product momen untuk menghitung korelasi antar skor pada tiap item dengan maksud untuk 
melihat kekuatan dari masing-masing item dalam mengukur apa yang akan peneliti ukur. Analisis uji validitas tersebut dilakukan dengan menggunakan software IBM SPSS (Sattistic Package for Social Science) versi 22.

Rumus Product Moment.

$$
r_{\text {hitung }}=\frac{n\left(\sum X_{i} Y_{i}\right)-\left(\sum X_{i}\right)\left(\sum Y_{i}\right)}{\sqrt{\left\{n \sum X_{i}^{2}-\left(\sum X_{i}\right)^{2}\right\}\left\{n \sum Y_{i}^{2}-\left(\sum Y_{i}\right)^{2}\right\}}}
$$

Keterangan :

Keterangan :

$r_{\text {hitung }}=$ Koefisien Korelasi

$X_{i}=$ Jumlah skor item

$Y_{i}=$ Jumlah skor total

$\mathrm{n}=$ Jumlah Responden

Sedangkan untuk menguji sejauh mana konsistensi internal dari alat ukur itu sendiri akan dilakukan uji reliabilitas, dalam hal ini penulis akan menggunakan teknik Alpha Cronbach:

$$
\frac{k}{k-1}\left(1-\frac{\sum S^{2} j}{S^{2} x}\right)
$$

Keterangan:

$\alpha=$ koefisien reliabilitas alpha

$\mathrm{k}=$ jumlah item

$\mathrm{Sj}=$ varians responden untuk item $\mathrm{I}$

$\mathrm{Sx}=$ jumlah varians skor total

Indikator pengukuran reliabilitas menurut Sekaran (2000: 312) yang membagi tingkatan reliabilitas dengan kriteria sebagai berikut :

Jika alpha atau $r$ hitung:

1. $0,8-1,0=$ Reliabilitas baik

2. $0,6-0,799=$ Reliabilitas diterima

3. kurang dari $0,6=$ Reliabilitas kurang baik

Analisis statistik yang digunakan dalam penelitian ini adalah analisis regresi linier sedrhana dengan mempergunakan program SPSS for windows versi 22.00. Analisis regresi berganda dipakai untuk menghitung besarnya pengaruh (variabel X) terhadap (variabel Y)

\section{Persamaan Regresi Sederhana}

Persamaan regresi sederhana diperoleh dengan rumus:

$$
\mathrm{Y}=\mathrm{a}+\mathrm{bX} \text {, dimana: }
$$

$\mathrm{Y}=$ Keunggulan Kompetitif (competitive advantage)

$\mathrm{X}=\quad$ Komunikasi Interpersonal

(Interpersonal communication)

$\mathrm{a}=$ Intersept (konstan)

$b=$ Koefisien regresi

Kriteria pengambilan keputusan untuk hipotesis yang diajukan adalah,

Kriteria keputusan:

Pada taraf kesalahan 0.05 dengan derajat kebebasan dk (n-2) serta pada uji satu pihak, yaitu uji pihak kanan. Secara statistik hipotesis yang akan diuji dalam rangka pengambilan keputusan penerimaan atau penolakan hipotesis dapat ditulis sebagai berikut:

Ho $=$ artinya tidak terdapat pengaruh yang signifikan antara Komunikasi Interpersonal terhadap keunggulan kompetitif SDM.

$\mathrm{Ha}=$ artinyaterdapat pengaruhyangsignifikan antara Komunikasi Interpersonal terhadap Keunggulan kompetitif SDM. 


\section{HASIL DAN PEMBAHASAN}

\section{Hasil Analisis Instrumen}

\section{a. Hasil Uji Validitas}

Dari hasil uji validitas yang telah dilakukan dengan menggunakan program computer SPSS version 22 maka dapat dilihat hasil uji validitas pada tabel di bawah ini.

Tabel hasil uji validitas Variabel X

\begin{tabular}{|l|l|l|l|}
\hline Item & Korelasi & r. Tabel & Kesimpulan \\
\hline X1 & 0.632 & 0.361 & Valid \\
\hline X2 & 0.605 & 0.361 & Valid \\
\hline X3 & 0.581 & 0.361 & Valid \\
\hline X4 & 0.485 & 0.361 & Valid \\
\hline X5 & 0.582 & 0.361 & Valid \\
\hline X6 & 0.322 & 0.361 & Tidak Valid \\
\hline X7 & 0.486 & 0.361 & Valid \\
\hline X8 & 0.677 & 0.361 & Valid \\
\hline X9 & 0.370 & 0.361 & Valid \\
\hline X10 & 0.685 & 0.361 & Valid \\
\hline X11 & 0.588 & 0.361 & Valid \\
\hline X12 & 0.593 & 0.361 & Valid \\
\hline X13 & 0.670 & 0.361 & Valid \\
\hline X14 & 0.444 & 0.361 & Valid \\
\hline X15 & 0.645 & 0.361 & Valid \\
\hline X16 & 0.641 & 0.361 & Valid \\
\hline X17 & 0.354 & 0.361 & Tidak Valid \\
\hline
\end{tabular}

Tabel Hasil Uji Validitas Variabel Y

\begin{tabular}{|l|l|l|l|}
\hline Item & Korelasi & F Tabel & Kesimpulan \\
\hline Y1 & 0.320 & 0.361 & Tidak Valid \\
\hline Y2 & 0.682 & 0.361 & Valid \\
\hline Y3 & 0.465 & 0.361 & Valid \\
\hline Y4 & 0.513 & 0.361 & Valid \\
\hline Y5 & 0.474 & 0.361 & Valid \\
\hline Y6 & 0.443 & 0.361 & Valid \\
\hline Y7 & 0.347 & 0.361 & Tidak Valid \\
\hline Y8 & 0.590 & 0.361 & Valid \\
\hline Y9 & 0.556 & 0.361 & Valid \\
\hline Y10 & 0.493 & 0.361 & Valid \\
\hline
\end{tabular}

\begin{tabular}{|l|l|l|l|}
\hline Y11 & 0.502 & 0.361 & Valid \\
\hline Y12 & 0.651 & 0.361 & Valid \\
\hline Y13 & 0.274 & 0.361 & Tidak Valid \\
\hline
\end{tabular}

Berdasarkan data pada tabel di atas pada variabel komunikasi interpersonal dapat dilihat item 6 dan item 17 yang tidak valid karena nilai Corrected item correlation lebih kecil dari nilai $\mathrm{r}$ tabel product momen 0.361 , maka dapat disimpulkan kedua item tersebut tidak layak digunakan dalam kuesioner. Sedangkan pada variabel keunggulan kompetitif item 1, item 7 dan item 13 yang tidak valid dan tidak layak digunakan untuk kuesioner.

b. Hasil Uji Reliabilitas

Nilai reliabilitas dilakukan dengan membandingkan antara nilai koefisien reliabilitas (r-hitung) dengan r-tabel sebagai berikut:

\begin{tabular}{|l|l|}
\hline \multicolumn{2}{|c|}{$\begin{array}{c}\text { Reliability Statistics } \\
\text { Var.Y }\end{array}$} \\
\hline $\begin{array}{l}\text { Cronbach's } \\
\text { Alpha }\end{array}$ & N of Items \\
\hline .737 & 10 \\
\hline
\end{tabular}

\begin{tabular}{|l|l|}
\hline \multicolumn{2}{|c|}{$\begin{array}{c}\text { Reliability Statistics } \\
\text { Var.X }\end{array}$} \\
\hline $\begin{array}{l}\text { Cronbach's } \\
\text { Alpha }\end{array}$ & N of Items \\
\hline .806 & 15 \\
\hline
\end{tabular}

Berdasarkan tabel di atas, dapat dilihat bahwa nilai Cronbach Alpha variabel komunikasi interpersonal sebesar 0.806 dan variabel keunggulan kompetitif sebesar 0.737 lebih besar dari 0.60 dapat disimpulkan kedua variabel tersebut memenuhi syarat sebagai alat ukur untuk pengambilan data penelitian. 
Berdasarkan hasil perhitungan analisis regresi linier antara komunikasi interpersonal human kapital terhadap keunggulan Kompetitif dengan menggunakan program SPSS diperoleh persamaan regresi yaitu:

$\mathrm{Y}=\mathrm{a}+\mathrm{bX}$

$\mathrm{Y}=14.566+0.389 \mathrm{X}$

\begin{tabular}{|l|l|l|l|l|l|}
\hline \multirow{2}{*}{ Model } & \multicolumn{2}{|l|}{$\begin{array}{l}\text { Unstandardized } \\
\text { Coefficients }\end{array}$} & $\begin{array}{l}\text { S tandard- } \\
\text { ized } \\
\text { Coefficients }\end{array}$ & $\mathrm{t}$ & Sig. \\
\cline { 2 - 6 } & $\mathrm{B}$ & $\begin{array}{l}\text { S t d . } \\
\text { Error }\end{array}$ & Beta & & \\
\hline $\begin{array}{l}\text { (Constant) } \\
\text { Komunikasi } \\
\text { Interpersonal }\end{array}$ & $\begin{array}{l}14.566 \\
.389\end{array}$ & $\begin{array}{l}5.418 \\
.089\end{array}$ & .403 & 2.688 & .008 \\
\hline
\end{tabular}

a. Variabel Dependen: Keunggulan Kompetitif

Koofesien regresi sebesar 0.389 berarti komunikasi interpersonal mempunyai pengaruh yang positif atau searah dengan Keunggulan kompetitif. Karena koofesioen bernilai positif maka setiap peningkatan 1 satuan komunikasi interpersonal sebagai modal capital maka akan berpengaruh terhadap peningkatan keunggulan kompetitif sumber daya manusia pada industri pariwisata Bangka sebesar 0.389 satuan. Untuk mengetahui ada tidaknya pengaruh Komunikasi Interpersonal terhadap Keunggulan kompetitif human capital sumber daya manusia pada industri pariwisata Bangka, maka dapat dilihat pada tabel ANOVA berikut ini:

ANOVA $^{\text {a }}$

\begin{tabular}{|l|l|l|l|l|l|l|}
\hline \multicolumn{2}{|l|}{ Model } & $\begin{array}{l}\text { Sum of } \\
\text { Squares }\end{array}$ & df & $\begin{array}{l}\text { Mean } \\
\text { Square }\end{array}$ & F & Sig. \\
\hline 1 & $\begin{array}{l}\text { Regres- } \\
\text { sion }\end{array}$ & 440.502 & 1 & 440.502 & 19.003 & $.000^{\mathrm{b}}$ \\
\cline { 2 - 7 } & $\begin{array}{l}\text { Re- } \\
\text { sidual }\end{array}$ & 2271.688 & 98 & 23.180 & & \\
\cline { 2 - 7 } & Total & 2712.190 & 99 & & & \\
\hline
\end{tabular}
a. Dependent Variabel: Keunggulan Kom- petitif
b. Predictors: (Constant), Komunikasi In- terpersonal

Dari tabel di atas dapat diketahui bahwa tingkat signifikansinya sebesar 0.000 atau dengan kata lain $0.0 \%$ yang nilainya jauh lebih kecil dari $\alpha 0,05$ maka hipotesis nol (H0) ditolak dan dan hipotesis alternatif (Ha) diterima, maka dapat disimpulkan bahwa model regresi, yaitu Komunikasi Interpersonal sebagai modal manusia mempengaruhi keunggulan kompetitif sumber daya manusia pada industri pariwisata. Untuk mengetahui besarnya tingkat pengaruh,maka dapat dilihat dalam tabel berikut:

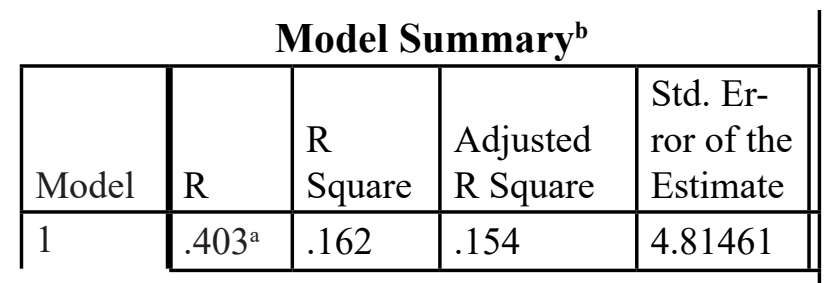

a. Predictors: (Constant), Komunikasi Interpersonal

b.Variabel Dependen: Keunggulan Kompetitif

Tabel model summary tersebut terdapat $\mathrm{R}$ Square 0,162 atau dengan kata lain 16.2\% berarti variabel terikat dipengaruhi oleh variabel bebas sebesar $16.2 \%$. Hal ini bisa juga diartikan bahwa Komunikasi Interpersonal sebagai modal manusia mempunyai pengaruh yang rendah terhadap keunggulan kompetitif sumber daya manusia pada industri pariwisata di Bangka.Variabel bebas X memiliki pengaruh kontribusi sebesar 16.2\% terhadap variabel $Y$ dan $83.8 \%$ dipengaruhi oleh faktor-faktor lain di luar variabel X. 


\section{KESIMPULAN}

Dari hasil analisis data yang dilakukan oleh peneliti terkait judul penelitian Pengaruh Komunikasi Interpersonal Terhadap Peningkatan Keunggulan Kompetitif Human Capital Manusia pada Industri Pariwisata Bangka maka dapat disimpulkan bahwa komunikasi interpersonal sebagai modal manusia berpengaruh positif dan signifikan pada keunggulan kompetitif sumber daya manusia di industri Pariwisata Bangka. Hal ini dinyatakan bahwa semakin baik komunikasi intrpersonal yang dimiliki para pelaku bisnis jasa industri pariwisata kota Bangka maka akan lebih unggul daya saingnya dibandingkan dengan Pelaku bisnis pariwisata di negara- negara ASEAN lainnya sehingga akan merangsang minat wisatawan untuk datang berwisata ke Bangka. Dan lebih dari pada itu sangat penting sekali bagi SDM memiliki modal pengetahuan sebagai modal manusia itu sendiri untuk menunjang kemampuan serta skill dalam meraih keunggulan dalam bersaing.

\section{SARAN}

Berdasarkan hasil dan kesimpulan yang telah diuraikan di atas maka penulis mengajukan saran kontribusi Komunikasi interpersonal hanya sebesar $16.2 \%$ terhadap Keunggulan Kompetitif SDM berarti $83.8 \%$ dipengaruhi oleh faktor lain yang memiliki kontribusi untuk meningkatkan daya saing SDM. Oleh karena itu penelitian selanjutnya diharapkan melibatkan variabelvariabel lain yang diduga dapat berkontribusi meningkatkan daya saing SDM pada idustri pariwisata, misalnya promosi melalui Word of Wouth, media sosial maupun variabel lainnya.

\section{DAFTAR PUSTAKA}

Agung, A. M. Lilik. 2007. Human Capital Competencies Sketsa-Sketsa Praktik

Human Capital Berbasis Kompetensi. Jakarta: PT. Elex Media Komputindo.

Becker, Gary S. (1993). Human Capital, Chicago: University of Chicago Press.

Cravens, David W. (1996). Pemasaran Strategis Jilid 1. Jakarta: Erlangga

Davenport, Thomas. 1993. "Process Innovation: Reengineering Work Through Information Technology". Boston: Havard Business School Press.

Devito, J. (1989). The Interpersonal Communication Book. Fifth edition. New York: Harper and Row Publishers

Devito, J.A. (1978). Communicology: An Introduction to the Study of Communication. NewYork: Harper Collins Publisher Inc.

Kuncoro, Mudrajad. 2005. Strategi Bagaimana Meraih Keunggulan Kompetitif. Jakarta: Elangga.

Logenecker, J.G., J.W. Petty dan C.W. Moore. 2003.Small Business Manajement :An Entrepreneurial Emphasis, Australia : Thomson, pp. 30, 31, 33

Mulyana, Deddy. 2005. Ilmu komunikasi : Suatu Pengantar. Bandung : Remaja

Rosdakarya.

Porter, Michael E. (1994). Keunggulan bersaing, Menciptakan dan Mempertahankan Kinerja Unggul. Jakarta : Binarupa Aksara . Komunikasi Konsep dan Aplikasi. Jakarta: PT. Raja Grafindo Persada. 
Ruslan, Rosady. 2005. Manajemen Publik Relation dan Media

Undang-undang Republik Indonesia Nomor 10 Tahun 2009 tentang Kepariwisataan

William, D. Brooks dan Philip Emert. 1976. Konsep Diri Manusia . Jakarta: EGC 